\title{
The First International Conference on Arabs' and Muslims' History of Sciences
}

The College of Arts and Sciences of the University of Sharjah, United Arab Emirates, organized a four-day landmark event, The First International Conference on Arabs' and Muslims' History of Sciences, during 24-27 March 2008. Entitled "Arabs' and Muslims' Scientific Contributions to Humanity," it was held under the patronage of His Highness Sheikh Dr. Sultan bin Mohammed al-Qasimi (member of the Supreme Council, ruler of Sharjah, and supreme president of the University of Sharjah) in collaboration with the university's College of the Shari`ah and Islamic Studies and the Arab Union of Astronomy and Space Sciences (AUASS). The conference sought to highlight the testimonies of non-Muslim scholars concerning Arab and Muslim scholars' scientific accomplishments and to emphasize their contributions to medicine, astronomy, architecture, and agriculture. Over 300 participants from 200 scientific and research institutions in 35 countries attended, and about 250 research papers, which will be available on the university's website (https://www.sharjah.ac.ae/), were presented.

The conference created an intellectual platform to enhance communication among scientists and researchers studying the history of the various sci- 
ences, highlight the Muslim scientists' impact on advancing civilization, and documenting the testimonies of non-Muslim scientists who recognize the Muslims' scientific achievements. The papers analyzed four focal themes:

1. Scientific Structure in Islamic Civilization: Science and Mind in Islam: A Comparative Analysis; The Impact of Muslims' Methods of Scientific Research on the Development of Science; and Man and the Universe from an Islamic Perspective.

2. Contributions of Muslim Scientists in the Fields of Astronomy, Basic Space and Weather Sciences, Astronomical Observatories and Astronomical Applications in the Islamic Shari ah; Humanities; Medical Sciences; Basic and Applied Sciences (Mathematics, Chemistry, Physics, and Geosciences); Islamic Arts; Industrial Applications, Engineering and Mechanical Sciences; Agriculture, Soil, and Irrigation Sciences; and Geography and Oceanography.

3. Muslims' Contributions toward Enhancing Peaceful Coexistence among Civilizations.

4. Scientific Interaction between Civilizations from an Islamic Perspective: Principles of Scientific Interaction in Islam; Means of Scientific Convergence; NonMuslims' Recognitions of Muslims' Scientific Achievements; and Application and Samples.

Three very informative workshops were held. The first one, "Teaching Optics in Light of Ibn Al-Haitham's Principles," targeted high school physics teachers and was co-organized by the university's Radiation Science and Technology Research Group of the Applied Physics Department in cooperation with Professor Charles Falco, the world-renowned expert on Arab Optics from the College of Optical Sciences, University of Arizona. The second workshop, "Tradition of Astronomy, Space, and Weather Sciences (Astronomical Applications to the Islamic Shari ah)," addressed issues related to crescent visibility from an Islamic perspective. The final one was on herbal medicine. Several very interesting exhibitions were featured: a Traditional Scientific Manuscript Exhibit, a 1001 Exhibition (consisting of portraits, pictures, manuscripts, and instruments of the golden age of Arabic sciences assembled by the Arabic Institute in France); an exhibit for Juma'a AlMajid's institution highlighting its efforts to restore manuscripts; and the Sky Project (by SELEFA Astronomical Society of France).

The conference organizers urged Muslims to remain focused on education, saying that the Arab world had formalized education and that the caliphs had attracted to their courts scientists, poets, physicians, and philosophers whom they then supported. Learning progressed and developed, for differences of creed, color, race, and tribe were not barriers to learning. In the early periods, the mosque served as the fundamental educational institu- 
tion. The jami ah (university) emerged from the madrasah. The Guinness Book of World Records recognizes the University of Al-Karaouine (Jami at al-Qarawiyyin) founded in Fez (Morocco) in 859, as the world's oldest university. Cairo's al-Azhar University, founded in 969, offered a wide variety of academic degrees, including post-graduate degrees, and was the first fully fledged university. The modern-day graduation ceremonies resemble the ceremonies held by these classical-era Arab universities. The robes worn today were called jubbat al-faqih and were given when an ‘alim (scholar) received his license to teach (ijazah).

This event proved to be the ideal platform for establishing the first Arabic-Islamic International Association for the History of Muslim Sciences with its headquarters in Sharjah. Branches/chapters are expected soon at several Arabic and Islamic universities. Similar conferences are needed to address the urgent issues surrounding the history of sciences, particularly from an Arab perspective. This conference is the first building block of a well-established institute at the University of Sharjah with an independent entity that will be the beginning of further conferences in this field. These conferences will enable scientific institutions and research centers to develop strategies to propagate the Arab and Islamic scientific heritage via establishing a scholarly methodology for editing, studying, and publishing manuscripts in their original languages and translating them. More information is available at www.sharjah.ac.ae/English/Conferences/ arabsandmuslims/Pages/ConferenceInformation.aspx.

The University of Sharjah, a non-profit institution for higher education established in October 1997, comprises twelve colleges that offer diverse academic programs catering to over 7,000 students with approximately 400 faculty members. The Arab Union of Astronomy and Space Sciences (www.jas. org.jo/union.html), established in 1998 during a conference organized by the Jordanian Astronomical Society, has a special committee, the Crescents' Observation and Mawaqeet Committee, to address issues surrounding moon sighting and the Islamic calendar. It has organized several Islamic astronomical conferences. 